\title{
Comparative Study of Nitrated Aromatic Hydrocarbons in Drinking Water samples taken from Hattar industrial area, TIP housing society, Hazara University Dhodial Mansehra and Kahuta industrial triangle Islamabad, Pakistan
}

\author{
Sohail Ahmad', Faisal Shahzad², Mukhtiar Hassan ${ }^{3}$, Babar Shah², Ayesha Babar 4 , \\ Nadia Parveen ${ }^{5}$, Ramsha Abbas ${ }^{6}, Z_{\text {Zuaira Alina }}{ }^{6}$, HaafizahKhansa Shabbir ${ }^{6}$, \\ Shabana Shams ${ }^{7}$, QaziAbdur Rashid ${ }^{1}$, Faiza Naseer ${ }^{{ }^{*}}$ \\ ${ }^{1}$ Department of Biochemistry, Hazara University, Mansehra, Pakistan \\ ${ }^{2}$ Department of Genetics, HazaraUniversity, Mansehra, Pakistan \\ ${ }^{3}$ Department of Microbiology, Hazara University, Mansehra, Pakistan \\ ${ }^{4}$ MSPH, Al Shifa school of Public Health, Rawalpindi, Pakistan \\ ${ }^{5 *}$ Department of Pharmacy, Government College, University Faisalabad, Pakistan \\ ${ }^{6}$ Institute of Pharmacy, Physiology and Pharmacology, University of Agriculture, Faisalabad, Pakistan \\ Department of Animal Sciences, Quaid e Azam University Islamabad, Pakistan

\begin{abstract}
Objective:Polycyclic aromatic hydrocarbons are teratogenic and mutagenic, for their determination 50 water samples were taken from Hattar industrial area, TIP housing society, Hazara University DhodialMansehra and Kahuta industrial triangle Islamabad. Methods: Samples were analyzed with the help of High Pressure Liquid Chromatography for the determination of 5 Nitro PAHs including: Nitronaphthalene $(N N)$, Nitrofluorine (NF), 9- Nitroanthracene (NA), 3-Nitrofluoroanthene (NFA), Nitropyrene (NP). Results: Maximum amount 1ng/L of 1-NN was detected in the water samples of Industrial Estate, Hattar.The samples taken from Hattar industrial Estate phase 1, 3-nitro PAHs were detected in different concentration, 9-NA = $0.4 n g / L, 2-N F=0.637 n g / L$ in $1^{\text {st }}$ sample and $0.34 n g / L$ in $2^{\text {nd }}$ sample, $1-N P$ 0.66ng/L, 0.21ng/L and 0.5ng/L in 3 different samples.The samples taken from Hattar industrial Estate phase 1V, 4-nitro PAHs were detected 1-NN $=1 n g / L, 0.69 n g / L, 2-N F=0.9 n g / L, 9-N A=0.87 n g / L$ and $1-N P=0.4 n g / L$. The sample taken form Kahuta Industrial Triangle, 4 nitro PHAs were detected $1-N N=0.42 n g / L, 2-N F=0.87 n g / L, 0.63 n g / L, 9-N A=$ $0.78 n g / L$ and $3-N F A=0.1 n g / L$. The sample taken from Industrial Estate I-9 Islamabad, only one nitro PAH 9$N A=0.41 n g / L$ was detected. The samples taken from TIP Housing Society, Industrial Zone Rawat Islamabad, Abbottabad, Qalanderabad, DhodialMansehraand commercial bottle of any beverages no nitro PAHs were detected.Bottled drinking water was also checked and no appreciable concentrations of nitro polycyclic aromatic hydrocarbons were detected in these samples. Conclusion: It is concluded that commercial water supplies are safe for health. The underground water near industrial areas particularly Hattar industrial area is not good for human use. While Rawat Industrial Zone is well planned for water supply and drainage so there no nitro PAHs were detected.
\end{abstract}

Keywords: Polycyclic aromatic hydrocarbons; High Pressure Liquid Chromatography; Islamabad; Nitronaphthalene; Nitrofluorine; 9- Nitroanthracene; 3-Nitrofluoroanthene

\section{INTRODUCTION}

Polycyclic aromatic hydrocarbons (PAHs) occur in oil, coal, and tar deposits and are produced as byproducts of fuel burning (whether fossil fuel or biomass) ${ }^{1,2}$. Some compounds have been identified as carcinogenic, mutagenic, teratogenic and potent atmospheric pollutants ${ }^{3}$.September 2012, NASA scientists reported results of analog studies in vitro that PAHs, subjected to interstellar medium (ISM) conditions, are transformed, through hydrogenation, oxygenation, and hydroxylation, to more complex organics"a step along the path toward amino acids and nucleotides, the raw materials of proteins and DNA, respectively"4. 
In a study evaluating the genotoxic and carcinogenic risks associated with the consumption of repeatedly heated coconut oil (RCO), one of the commonly consumed cooking and frying medium, it was concluded that dietary consumption of RCO can cause a genotoxic and preneoplastic change in the liver-9. Nitro-PAHs may be metabolized by ring oxidation, nitro reduction, as well as conjugation reactions. Some of these reactions may lead to reactive metabolites that can covalently bind to macromolecules including DNA. Reactive epoxides may be formed by various CYP enzymes ${ }^{6,10,11}$. The pollution of the environment by Nitrated polycyclic aromatic hydrocarbons is becoming a greater than ever ecological alarm. The interest and aim of this subject is to study that how much these compounds effect the health of human beings ${ }^{7,12}$.

The main objective of this research was to study the continual increased threat to the environment and human's wellbeing, to aware the Government as well as Environmental protection agencies about these carcinogenic compounds and their effects on health, to aware the ministry of environment that they should monitor/ check the waste treatment of industries and to aware the industrialists that they should provide safe/ pure drinking water to their employers

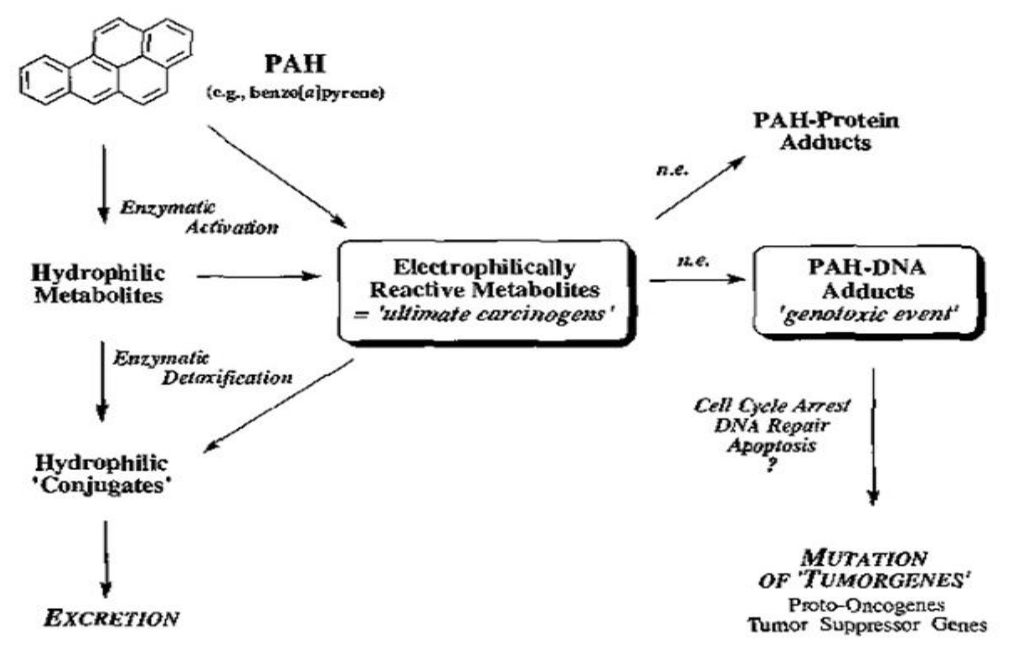

Figure 01. Strong role of polycyclic aromatic hydrocarbons as carcinogen

\section{Materials AND Methods}

\section{Experimental Design}

Fifty water samples from Hattar and Islamabad Industrial areas, residential area of TIP housing society, Jinnahabad and Hazara University as well as bottled water were analyzed for the presence of 1-Nitronaphthalene, 9-Nitroanthracene, 3-Nitrofluoranthene, 2-Nitrofluorene and 1-nitropyrene NitroPAHs. The analyses were performed by using an HPLC chromatograph. Individual Nitro-PAHs were identified through both retention time matches with authentic standards ${ }^{13,14}$.

\section{Sample collection and storage}

Samples were collected in containers made up of amber color glass bottles in refrigerator. All samples were kept at $4{ }^{\circ} \mathrm{C}$. $\mathrm{pH}$ is adjusted of the sample to $<2$ with $6 \mathrm{~N} \mathrm{HCl}$ to inhibit biological activity. All samples were extracted and completely analyzed within thirty days of extraction ${ }^{11}$.

\section{Extraction procedures:}

For liquid-liquid extraction, $100 \mathrm{ml}$ of water sample having $0.75 \mathrm{mg} /$ liter peranalyte was extracted with $30 \mathrm{ml}$ aliquots of methylene chloride. The combined extract was poured through a column having $10 \mathrm{~cm}$ of sodium sulfate (anhydrous), and the extract was collected. Flask and column was rinsed with $20 \mathrm{~mL}$ of methylene chloride. The organic solvent is evaporated in to dryness in the evaporative flask. The residue is resuspended in $4 \mathrm{~mL}$ of acetonitrile and refrigerated $\left(4^{\circ} \mathrm{C}\right)$ to store ${ }^{15}$, 16.

\section{Solid-Phase Extraction (SPE)}

Water sample was collected and filtered through a $0.45 \mu \mathrm{m}$ filter. About $20 \mathrm{ml}$ of water sample was collected by passing through C18 Column. Take $5 \mathrm{ml}$ from it in test tube, add $5 \mathrm{ml}$ of filtered methylene chloride and evaporate at water-bath. Cooled and $5 \mathrm{ml}$ of acetonitrile was added ${ }^{12}$. 
Comparative Study of Nitrated Aromatic Hydrocarbons in Drinking Water samples taken from Hattar industrial area, TIP housing society, Hazara University Dhodial Mansehra and Kahuta industrial triangle Islamabad, Pakistan

\section{Chromatographic Conditions:}

HPLC (Isocratic) with UV detection was used for separation and quantification of Nitro-PAHs. 35: 65 $\mathrm{v} / \mathrm{v}$ mixtures of Acetonitrile and water were used as mobile phase $(1 \mathrm{ml} / \mathrm{min} \text {. })^{17}$. Sample loop was of $0.1 \mathrm{ml}$ volume ${ }^{12,13}$. Every nitro-PAH was detected in definite wavelengths which were shown as follows: 9-NA at $250 \mathrm{~nm}, 2-\mathrm{NF}$ at $250 \mathrm{~nm}, 3-\mathrm{NF}$ at $230 \mathrm{~nm}, 1-\mathrm{NP}$ at $230 \mathrm{~nm}$ and1-NP at $210 \mathrm{~nm}$

\section{RESULTS AND DisCUSSION}

The study consisted of fifty (50) water samples from different areas of Abbottabad, Mansehra, Haripur and Islamabad. Different sources of water like tube well, tape water and bottled water were selected for this purpose. These samples were analyzed for nitro polycyclic aromatic hydrocarbons and compared with standard chromatogram in which we intentionally injected Nitro PAHs at the concentration of $10 \mu \mathrm{g} / \mathrm{L}$. As shown in Chromatogram of Standard.The results are presented in table 1 to 10 .

\section{Sample Taken From Hattar Industrial Estate (Phase I)}

Samples were collected in the vicinity of Hattar Industrial area Phase I. In these samples all the five nitro PAHs were detected because it is industrial area where a number of factories are working including Ghee Mills, Steel Mills and paper Mills. One of the reasons of the presence of Nitro PAHs in water is inadequate sewage system and improper waste disposal of the factories.

In Hattar Industrial area Phase I there are three nitro-PAHs detected. These are: 9-NA, 2-NF and1-NP. Concentrations of the Nitro-PAHs detected in Hattar Industrial area are shown in table 1 (in ng/L). In sample 1 from Hattar Industrial Area 9-Nitroanthracene is detected with a concentration of $0.41 \mathrm{ng} / \mathrm{L}$ which is shown in table 1 and figure 9.In sample 2, 3 and 5 1-NP was detected concentration of0.66, 0.21 and $0.5 \mathrm{ng} / \mathrm{L}$ respectively and shown in figure 10,11 and 13 while in sample 4 and 6, 2-NF was detected at the concentration of 0.637 and $0.34 \mathrm{ng} / \mathrm{L}$ respectively shown in figure 12 and 14

Table 1: Water sample taken from Hattar Industrial Estate (Phase I)

\begin{tabular}{|c|c|c|c|c|c|}
\hline \multirow{2}{*}{ Smp. \# } & \multicolumn{5}{|c|}{ Nitro PAHs (ng/ L) } \\
\cline { 2 - 6 } & 1-NN & 2-NF & $9-$ NA & 3- NFA & $1-$ NP \\
\hline I & --- & Nil & 0.41 & --- & 0.66 \\
\hline II & --- & Nil & ---- & --- & 0.21 \\
\hline III & --- & Nil & ---- & --- & -- \\
\hline IV & --- & 0.637 & ---- & --- & 0.5 \\
\hline V & --- & --- & --- & --- & -- \\
\hline VI & --- & 0.34 & --- & & \\
\hline
\end{tabular}

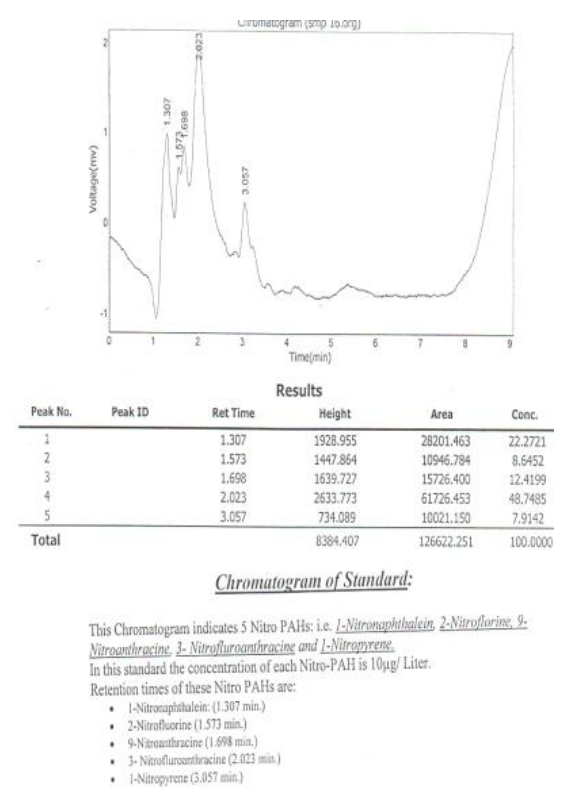




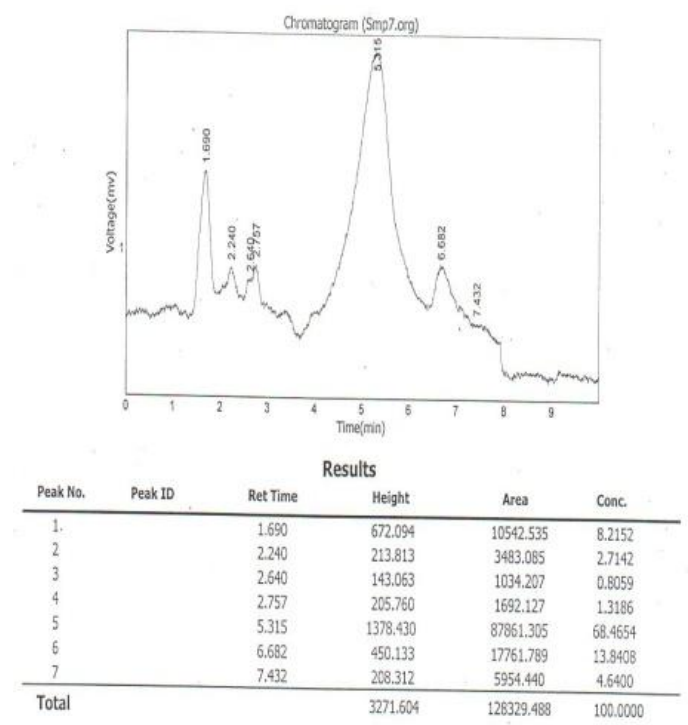

Fig1. Sample taken from Hattar Industrial area Phase I in which 9-NA was detected at a concentration of $0.4 \ln g / L$

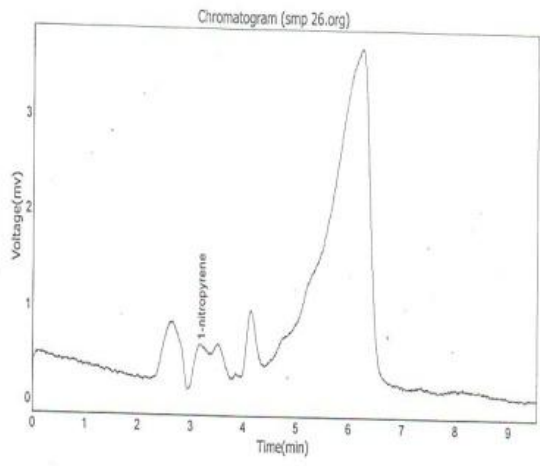

\begin{tabular}{cccccc}
\multicolumn{5}{c}{ Results } & \\
Peak No. & Peak ID & Ret Time & Height & Area & Conc. \\
\hline 1 & & 2.632 & 680.835 & 15136.950 & 5.9301 \\
2 & 1-nitropyrene & 3.198 & 485.388 & 8680.850 & 3.4008 \\
3 & & 3.532 & 495.598 & 8292.179 & 3.2485 \\
4 & & 3.857 & 180.828 & 1030.572 & 0.4037 \\
5 & 4.140 & 849.156 & 13286.029 & 5.2049 \\
6 & 4.832 & 590.517 & 11491.811 & 4.5020 \\
7 & 6.248 & 3621.160 & 197339.828 & 77.3099 \\
\hline Total & & 6903.481 & 255258.219 & 100.0000
\end{tabular}

Fig2: Sample taken from Hattar Industrial area Phase I in which 1-NP was detected at a concentration of $0.66 n g / L$
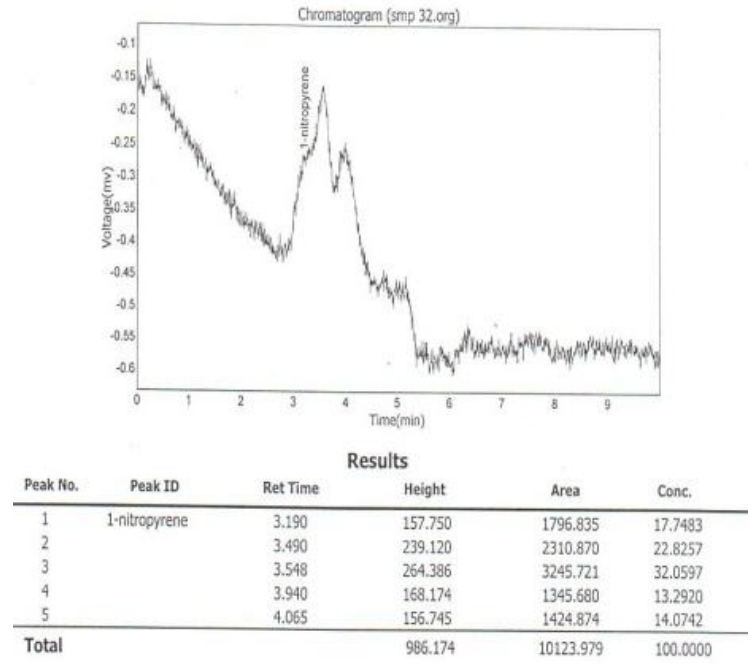

Fig3: Sample taken from Hattar Industrial area Phase I in which 1-Nitropyrene was detected at a concentration of $0.2 \operatorname{lng} / \mathrm{L}$ 
Comparative Study of Nitrated Aromatic Hydrocarbons in Drinking Water samples taken from Hattar industrial area, TIP housing society, Hazara University Dhodial Mansehra and Kahuta industrial triangle Islamabad, Pakistan
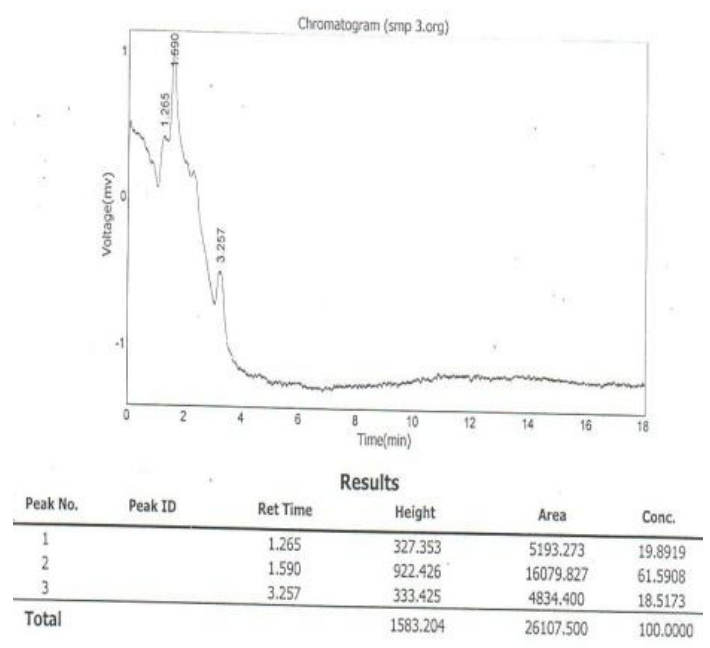

Fig4: Sample taken from Hattar Industrial area Phase I in which 2-Nitrofluorine was detected at a concentration of $0.637 \mathrm{ng} / \mathrm{L}$
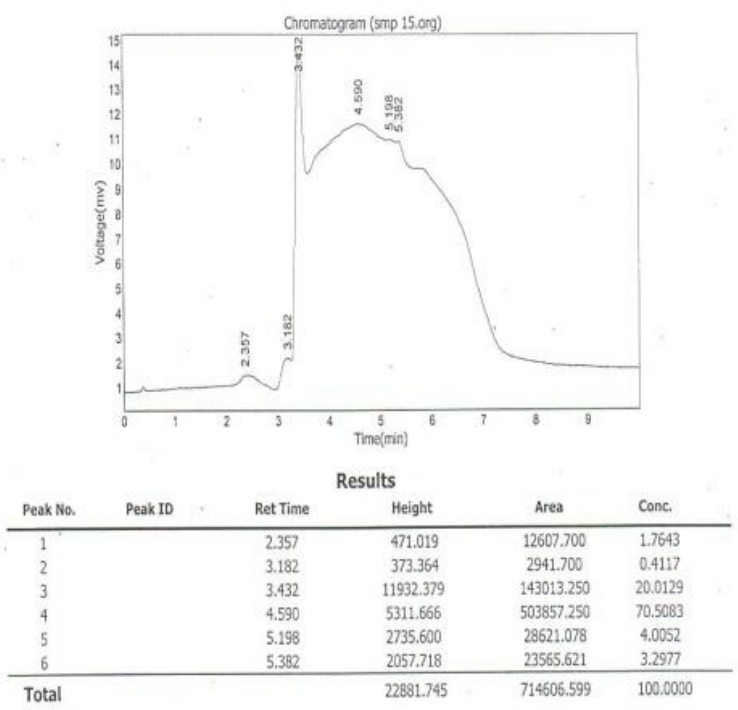

Figure 5: Sample taken from Hattar Industrial area Phase I in which 1-Nitropyrene was detected at a concentration of $0.66 \mathrm{ng} / \mathrm{L}$
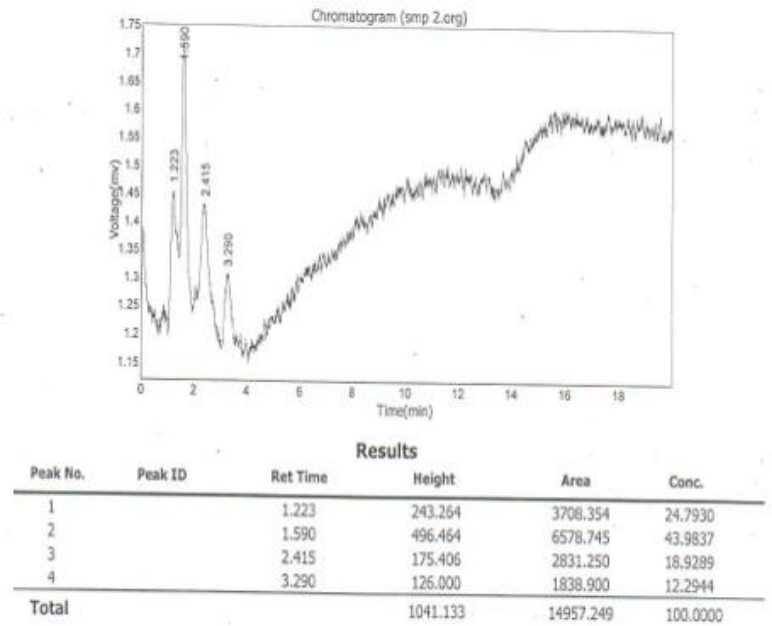

Figure 6: Sample taken from Hattar Industrial area Phase I in which 2-Nitrofluorine was detected at a concentration of $0.34 n g / L$ 


\section{Sample Taken From Hattar Industrial Estate (Phase IV)}

Samples were collected in the vicinity of Hattar Industrial area Phase IV. In these samples four nitro PAHs were detected because it is industrial area where a number of factories are working including DewanSulemanFibre, Steel Mills and chemicals manufacturing factories. One of the reasons of the presence of Nitro PAHs in water is inadequate sewage system and improper waste disposal of the factories.In Hattar Industrial area Phase IV there are four nitro-PAHs detected. These are:1Nitronaphthalene, 2-Nitrofluorine, 9-Nitroanthracene and 1-Nitropyrene.

In sample 01, 1-Nitronaphthalene was detected with a concentration of $1.00 \mathrm{ng} / \mathrm{L}$. In sample 03 there are three nitro-PAHs detected which are 1-NN, 2-NF, 9-NA with a concentration of $0.69,0.9$ and 0.87 respectively.

Table 2: Water sample taken from Hattar Industrial Estate (Phase IV)

\begin{tabular}{|c|c|c|c|c|c|}
\hline \multirow{2}{*}{ Smp. \# } & \multicolumn{5}{|c|}{ Nitro PAHs (ng/ Liter) } \\
\cline { 2 - 6 } & $1-\mathrm{NN}$ & $2-\mathrm{NF}$ & $9-\mathrm{NA}$ & $3-\mathrm{NFA}$ & 1- NP \\
\hline I & 1.00 & --- & --- & -- & --- \\
\hline II & --- & ---- & ---- & --- & -- \\
\hline III & 0.69 & 0.9 & 0.87 & --- & 0.40 \\
\hline IV & --- & --- & --- & - & - \\
\hline
\end{tabular}

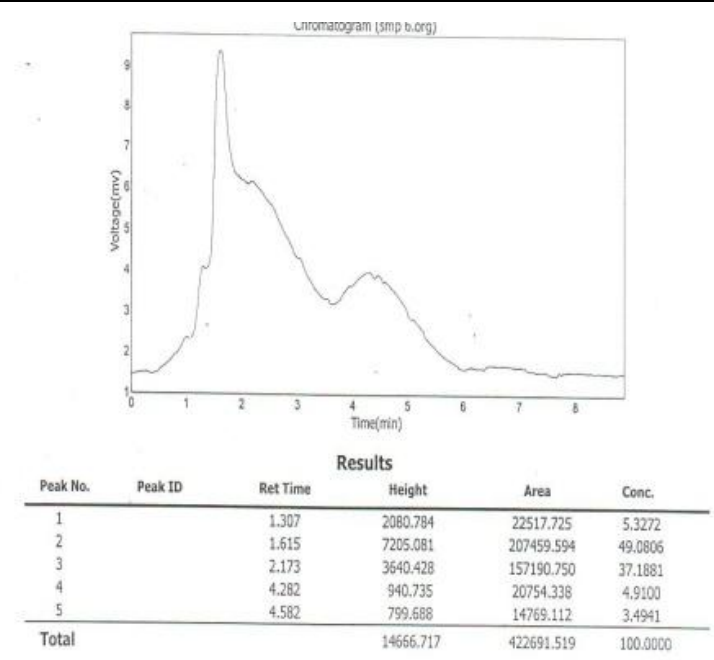

Fig7: Sample taken from Hattar Industrial area Phase IV in which 1-Nitronaphthalene was detected at a concentration of $1 \mathrm{ng} / \mathrm{L}$
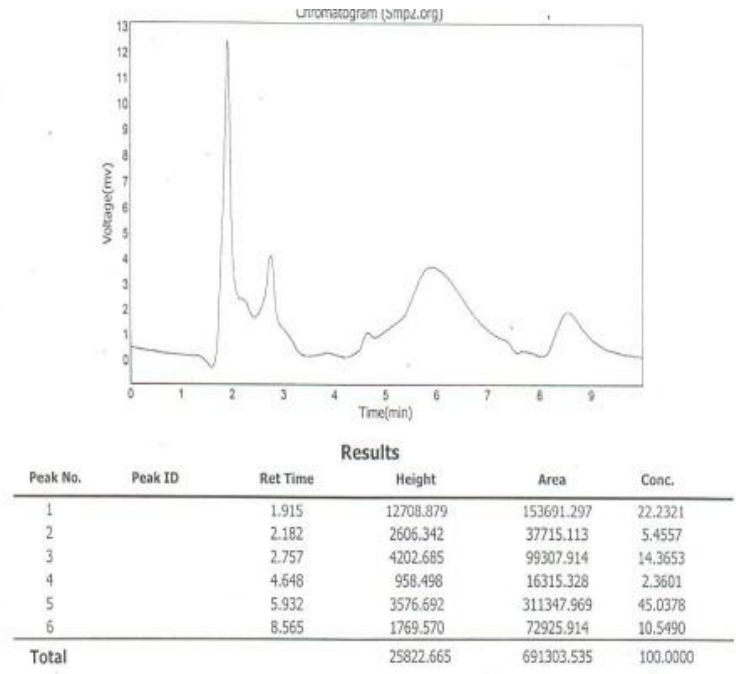

Fig8: Sample taken from Hattar Industrial area Phase IV in which 1-Nitronaphthalene wasdetected at a concentration of $1 n g / L$ 
Comparative Study of Nitrated Aromatic Hydrocarbons in Drinking Water samples taken from Hattar industrial area, TIP housing society, Hazara University Dhodial Mansehra and Kahuta industrial triangle Islamabad, Pakistan

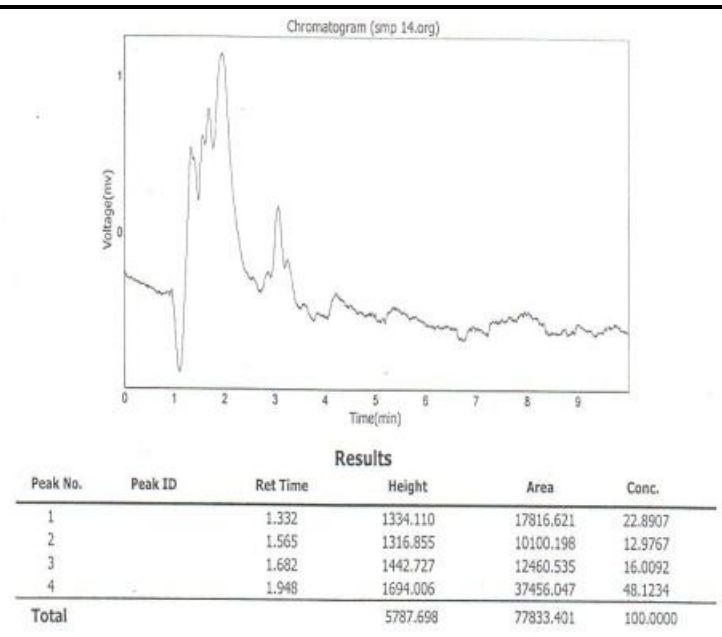

Fig9: Sample taken from Hattar Industrial area Phase IV in which three nitro-PAHs were detected: 1Nitronaphthalene $=0.69 \mathrm{ng} / \mathrm{L}, 2$-Nitrofluorine $=0.90 \mathrm{ng} / \mathrm{L}$ and 9 -Nitroanthracene $=0.87 \mathrm{ng} / \mathrm{L}$

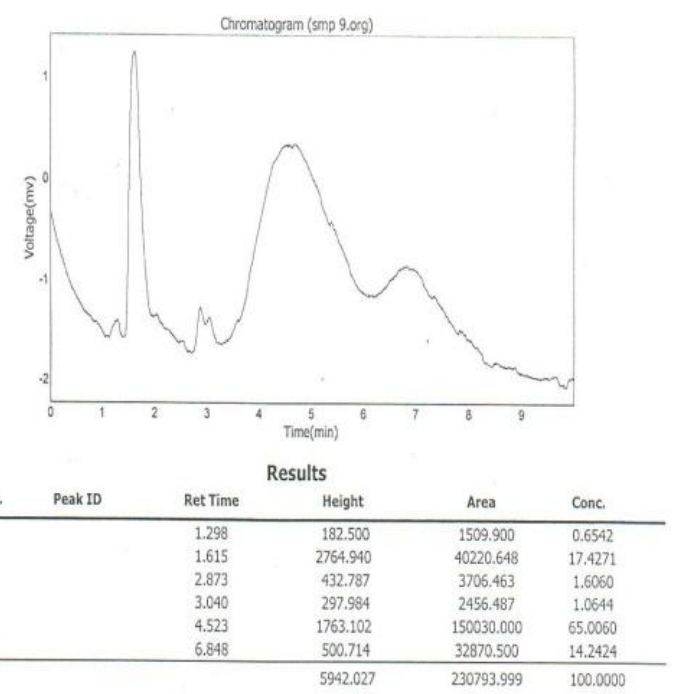

Fig10: Sample taken from Hattar Industrial area Phase IV in whichl-Nitropyrene was detected at a concentration of $0.4 \mathrm{ng} / \mathrm{L}$

\section{Samples Taken From Industrial Triangle Kahuta Road Islamabad}

These samples were collected from Industrial Triangle Kahuta Road, Islamabad. In these samples Nitro PAHs are detected as well because this is also industrial area. One of the reasons of the presence of Nitro PAHs in water is inadequate sewage system and improper waste disposal of the factories.Three water samples were collected from Kahuta Industrial estate,. Four Nitro-PAHs are detected in these samples taken from Industrial Triangle Kahuta road. In sample \# 01 there was no nitro-PAH detectedAnd in \# 02 four Nitro-PAHs were detected which are 1-NN $(0.42 \mathrm{ng} / \mathrm{L}), 2-\mathrm{NF}$ $(0.87 \mathrm{ng} / \mathrm{L}), 9-\mathrm{NA}(0.78 \mathrm{ng} / \mathrm{L}), 3-\mathrm{NFA}(0.1 \mathrm{ng} / \mathrm{L})$. In sample \# 03 2-NF was detected with a concentration of $0.63 \mathrm{ng} / \mathrm{L}$.

Table 3: Water sample taken from Industrial Triangle Kahuta road Islamabad

\begin{tabular}{|c|c|c|c|c|c|}
\hline \multirow{2}{*}{ Smp. \# } & \multicolumn{5}{|c|}{ Nitro PAHs (ng/ Liter) } \\
\cline { 2 - 6 } & 1-NN & 2-NF & 9- NA & 3-NFA & 1- NP \\
\hline I & --- & --- & -- & -- \\
\hline II & 0.42 & 0.87 & 0.78 & 0.1 & --- \\
\hline III & --- & 0.63 & --- & --- & - \\
\hline
\end{tabular}




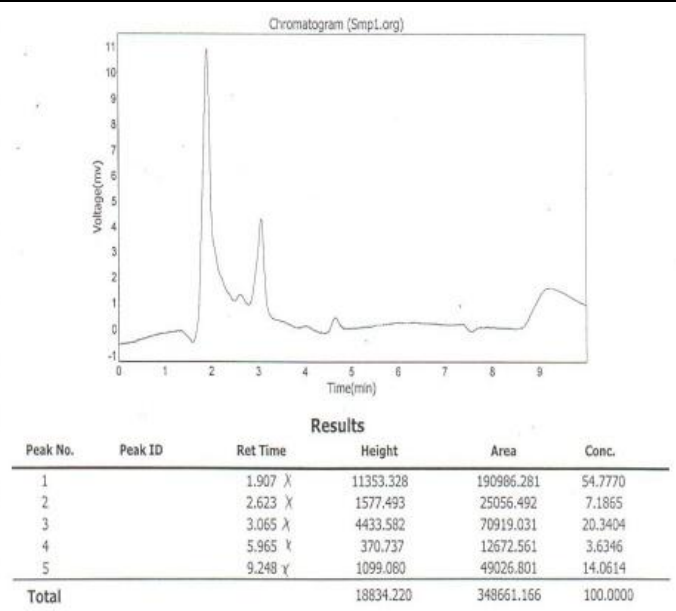

Fig11: Sample taken from Industrial Triangle Islamabad in which No nitro-PAH was detected.
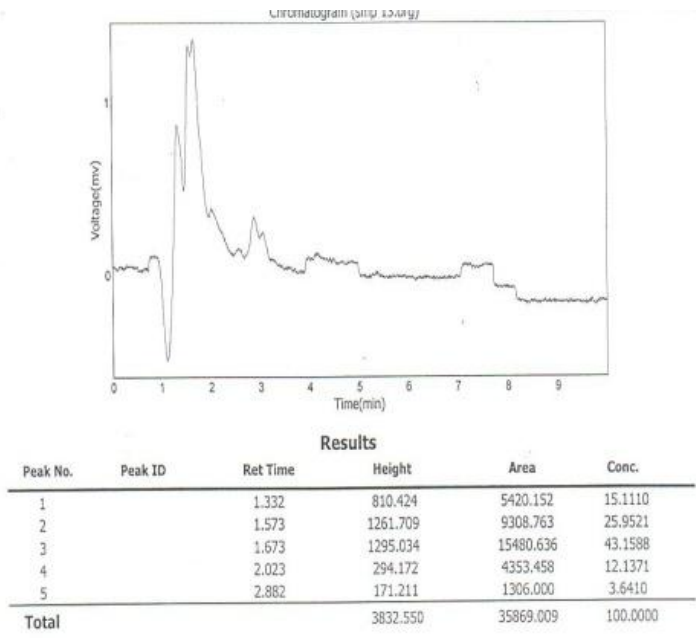

Fig12: Sample taken from Industrial Triangle Islamabad in which 1-NN, 2-NF, 9-NA, and 3-NF was detected.
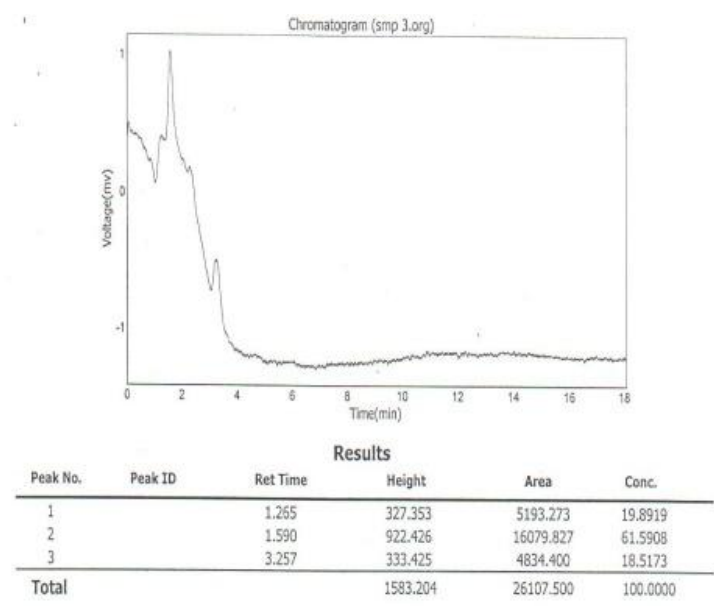

Fig13: Sample taken from Industrial Triangle Islamabad in which 2-NF was detected with a concentration of $0.63 n g / L$

\section{Sample Taken From Tip Housing Society, Haripur}

The data about level of PAHs in water samples collected from TIP housing society is given in table 04. The results show that no concentration of PAHs was found in these samples as the area of TIP colony is well planned and environmentally cleaned. Five samples were taken from different sources like tube well, tap water, and these samples were taken from different sectors of society. None of the samples contain any nitro-PAHs. Results are shown in table 04 and chromatograms are shown in figure 22 to 26 . 
Comparative Study of Nitrated Aromatic Hydrocarbons in Drinking Water samples taken from Hattar industrial area, TIP housing society, Hazara University Dhodial Mansehra and Kahuta industrial triangle Islamabad, Pakistan

Table 4: Water sample taken from TIP housing society, Haripur.

\begin{tabular}{|c|c|c|c|c|c|}
\hline \multirow{2}{*}{ Smp. \# } & \multicolumn{5}{|c|}{ Nitro PAHs (ng/ Liter) } \\
\cline { 2 - 6 } & $1-N N$ & $2-N F$ & $9-$ NA & 3-NFA & $1-$ NP \\
\hline I & --- & --- & --- & --- \\
\hline II & --- & --- & --- & --- & --- \\
\hline III & --- & --- & --- & --- & -- \\
\hline IV & --- & --- & --- & --- \\
\hline V & --- & --- & --- & - & - \\
\hline
\end{tabular}

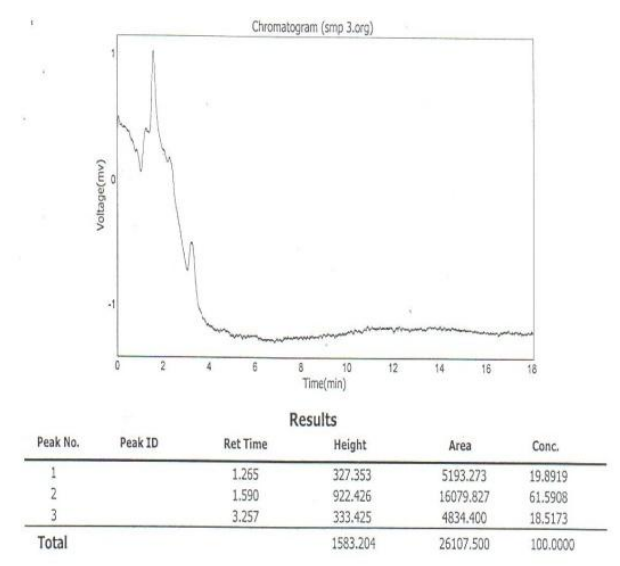

Figure 14: Sample taken from TIP housing society, Haripur in which No nitro-PAH was detected
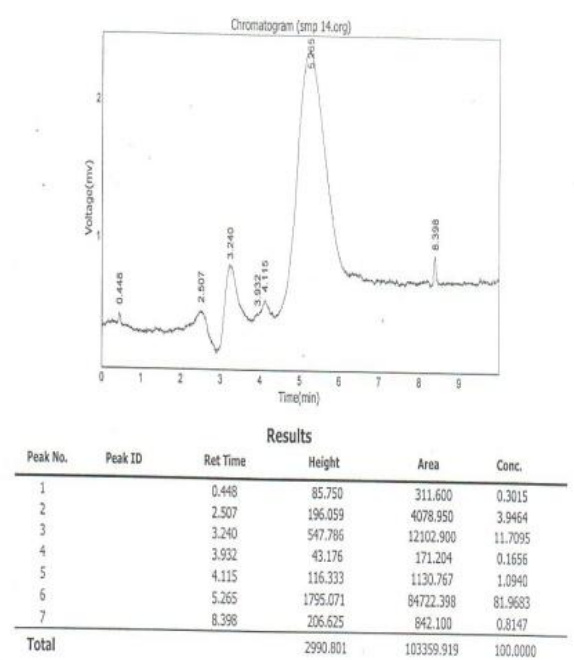

Fig15: Sample taken from TIP housing society, Haripur in which No nitro-PAH was detected

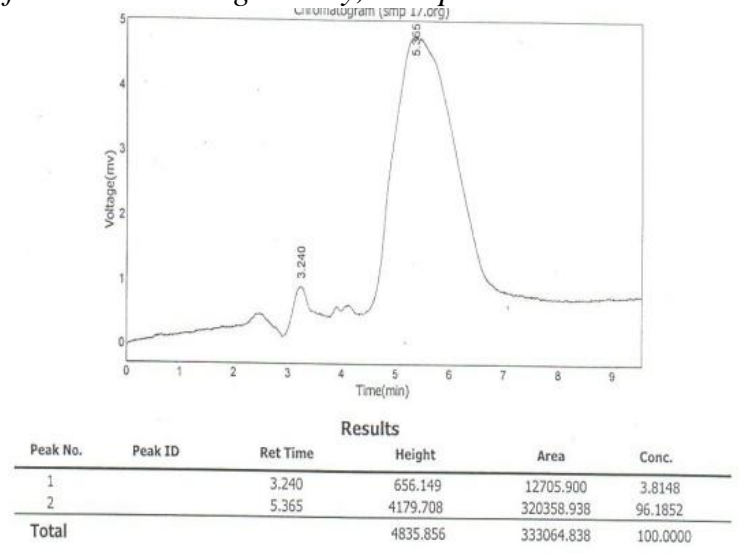

Figure 16: Sample taken from TIP housing society, Haripur in which No nitro-PAH was detected 


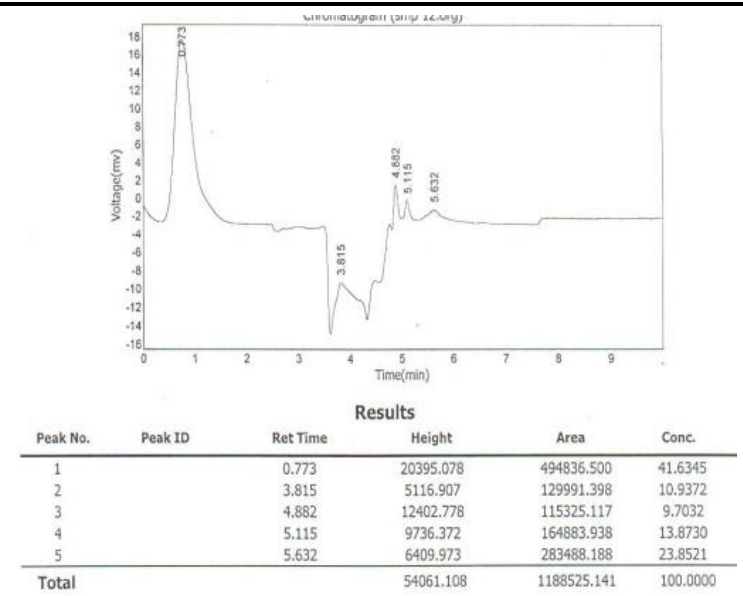

Fig17: Sample taken from TIP housing society, Haripur in which No nitro-PAH was detected
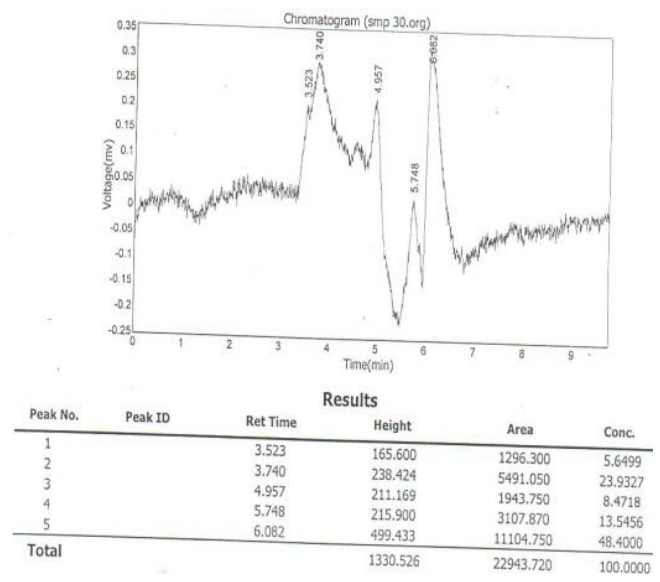

Fig18: Sample taken from TIP housing society, Haripur in which No nitro-PAH was detected

\section{Sample Collected From Bottled Mineral Water}

Table 05 presents the information about PAHs detected in commercially available mineral water sold in plastic bottles with trade names of NESTLE, KINLEY, AQUAFINA and SPARKLY. This data had shown no nitro PAHs were detected in bottled water which means that they have a good source of water and their water treatment is good.

Table 5: Water sample taken from Bottles (Nestle, Kinley, Aquafina and Sparkly)

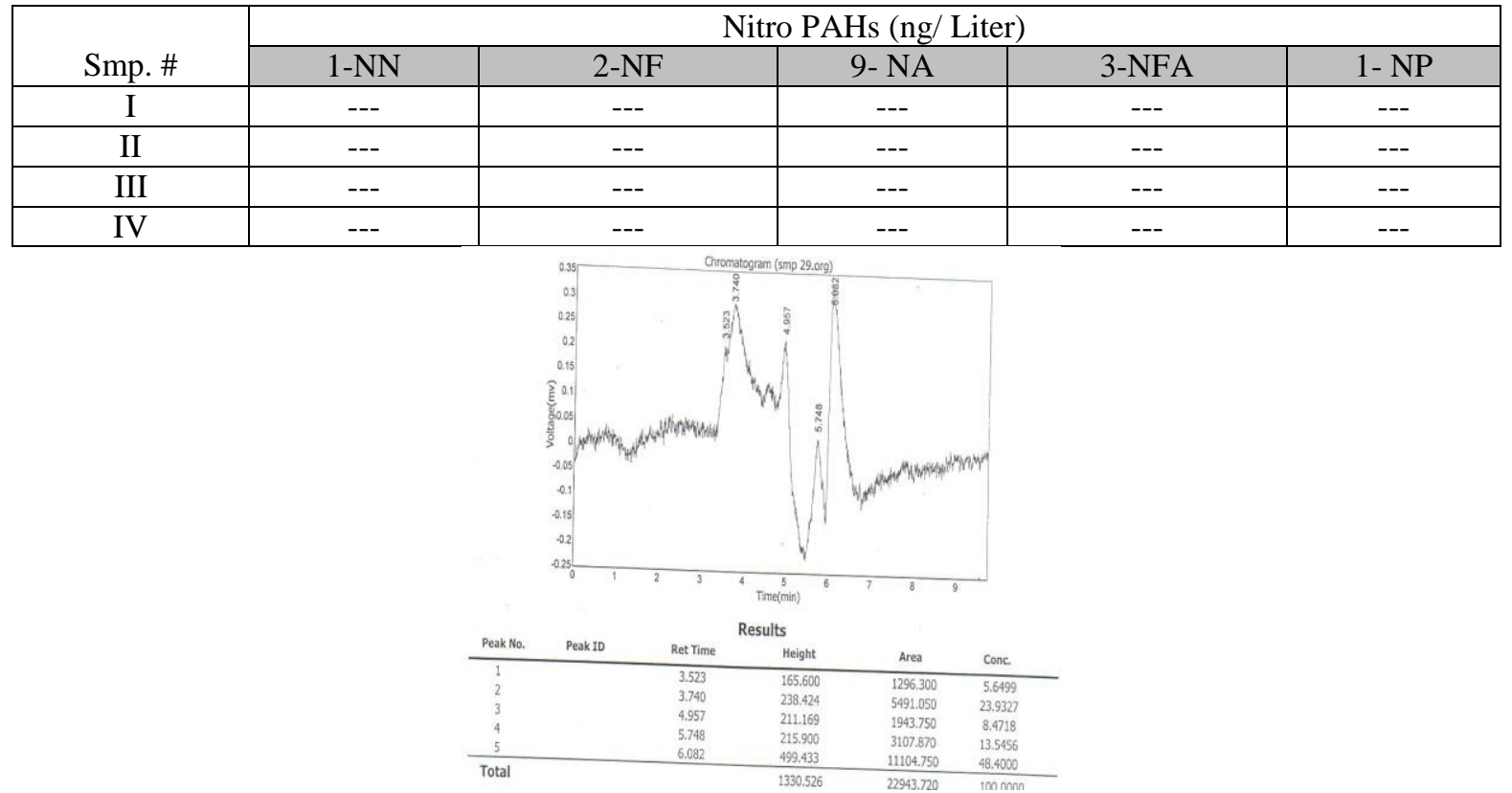

Fig19: Sample taken from Bottled water (NESTLE) No nitro-PAH was detected 
Comparative Study of Nitrated Aromatic Hydrocarbons in Drinking Water samples taken from Hattar industrial area, TIP housing society, Hazara University Dhodial Mansehra and Kahuta industrial triangle Islamabad, Pakistan

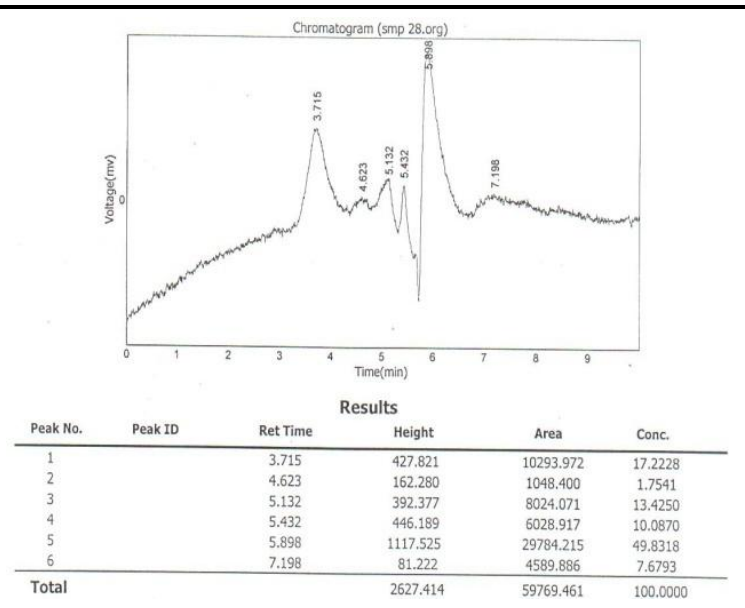

Fig20: Sample taken from bottled water (AQUAFINA) No nitro- PAH was detect

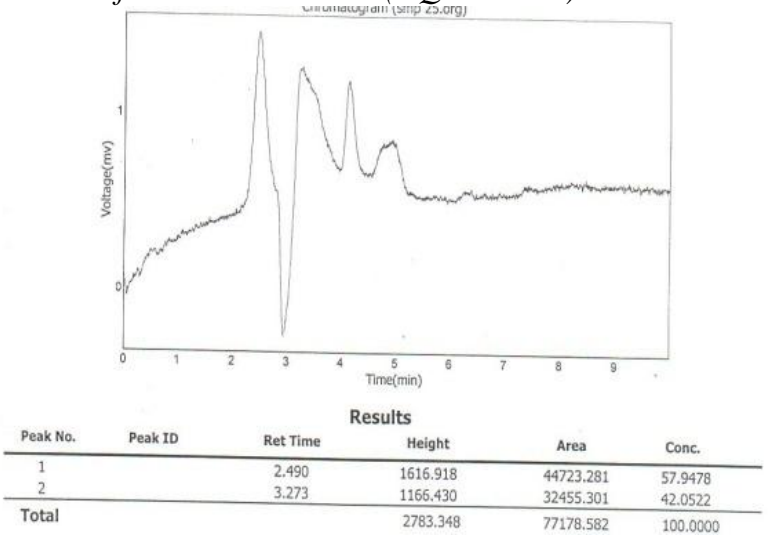

Fig21: Sample taken from bottled water (SPARKLEY) No nitro- PAH was detected
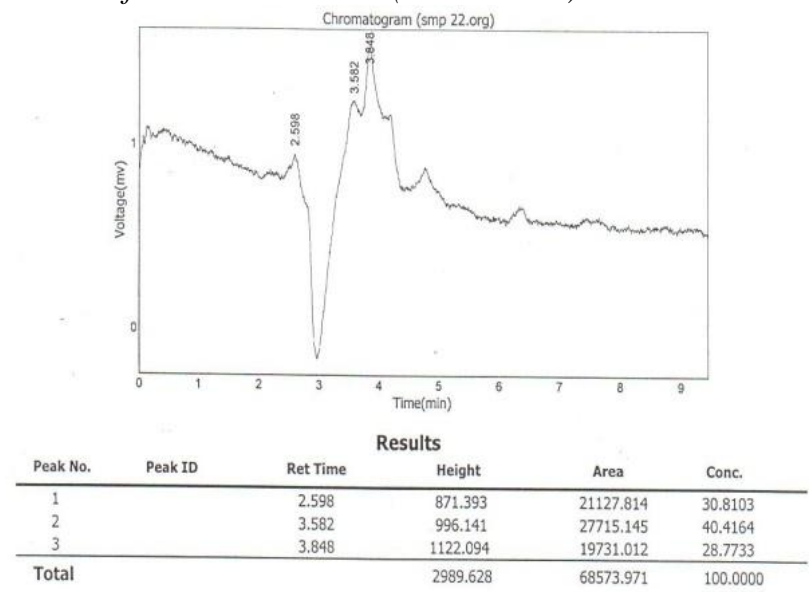

Fig22: Sample taken from bottled water (KINLEY) No nitro- PAH was detected

\section{Water Samples Taken From I-9 Industrial Estate Islamabad}

Table 06 presents the data of samples which were taken for analysis from I-9 industrial area, Islamabad, where only one nitro PAH is detected because it is also an industrial area. 9Nitroanthracine is detected here.

Table 6: Water sample taken from I-9 Industrial Estate, Islamabad

\begin{tabular}{|l|l|l|l|l|l|}
\hline \multirow{2}{*}{ Smp. \# } & \multicolumn{5}{l|}{ Nitro PAHs (ng Liter) } \\
\cline { 2 - 6 } & $1-N N$ & $2-N F$ & $9-N A$ & $3-N F A$ & $1-N P$ \\
\hline I & --- & --- & --- & --- & --- \\
\hline II & --- & --- & --- & --- & --- \\
\hline III & --- & --- & 0.41 & --- & --- \\
\hline IV & --- & --- & --- & --- & --- \\
\hline
\end{tabular}




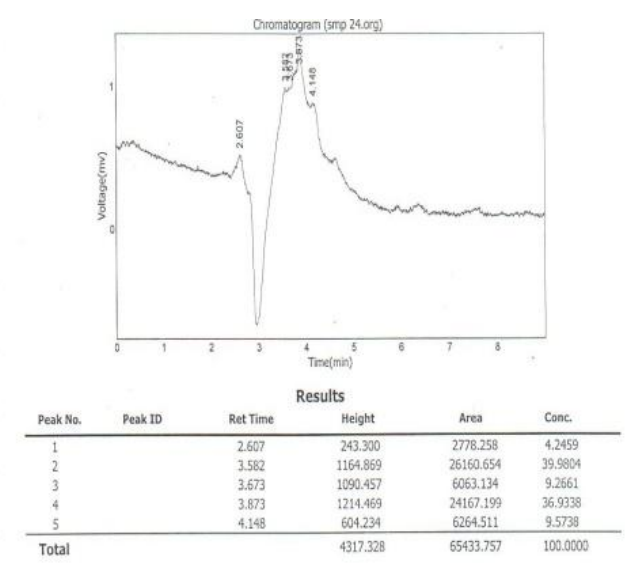

Fig23: Sample taken from I-9 Industrial Estate Islamabad in which No nitro-PAH was detected

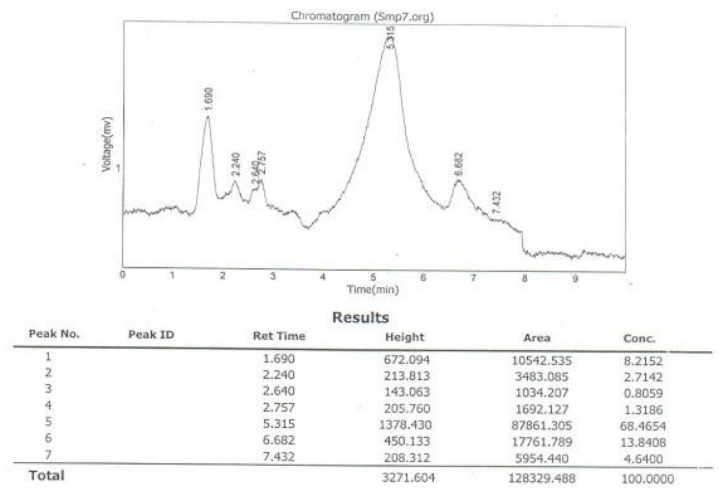

Fig24: Sample taken from I-9 Industrial Estate Islamabad in which No nitro-PAH was detected
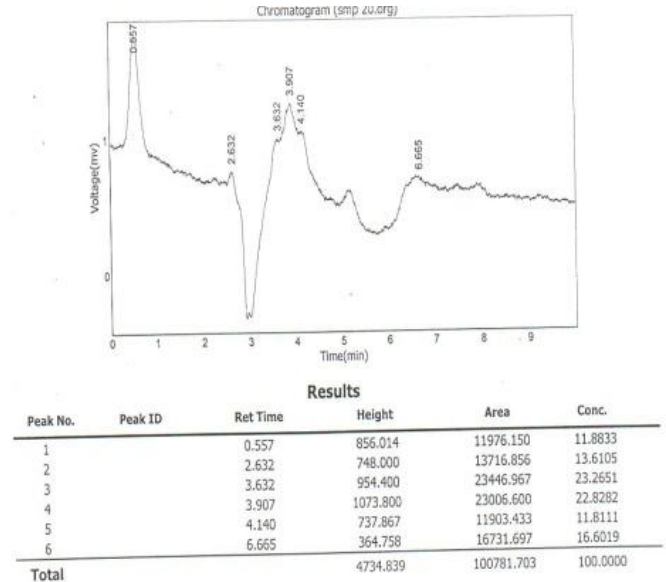

Fig25: Sample taken from I-9 Industrial Estate Islamabad in which 9-NA was detected at a concentration of $0.4 \operatorname{lng} / L$

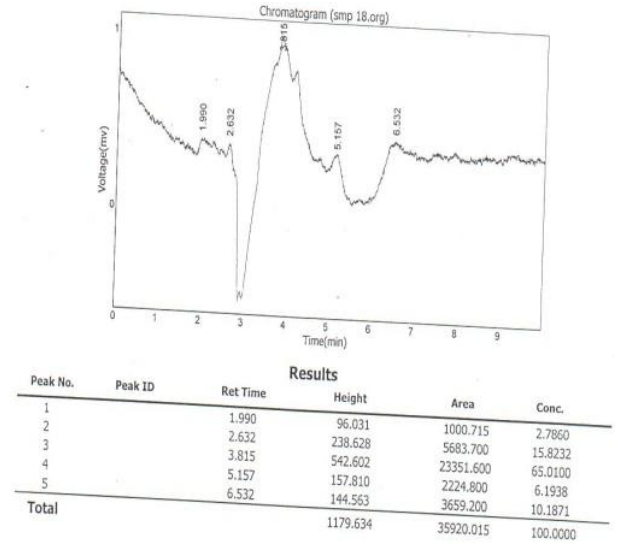

Fig26: Sample taken from I-9 Industrial Estate Islamabad in which No nitro-PAH was detected 
Comparative Study of Nitrated Aromatic Hydrocarbons in Drinking Water samples taken from Hattar industrial area, TIP housing society, Hazara University Dhodial Mansehra and Kahuta industrial triangle Islamabad, Pakistan

\section{Water Samples Taken From Jinnah Abad, Abbottabad}

Samples collected from Jinnahabad, Abbottabad are presented in table 7 and their chromatograms are shown in figure $35,36,37,38$ and 39 below. No nitro-PAH was detected in any of the samples taken from this vicinity. This was probably because there was no industrial area nearby and also the source of water is very good.

Table 7: Water samples taken from Jinnah Abad, Abbottabad

\begin{tabular}{|c|c|c|c|c|c|}
\hline \multirow{2}{*}{ Smp. \# } & \multicolumn{5}{|c|}{ Nitro PAHs (ng/ Liter) } \\
\cline { 2 - 6 } & $1-N N$ & $2-N F$ & $9-$ NA & $3-N F A$ & $1-$ NP \\
\hline I & --- & --- & --- & -- & --- \\
\hline II & --- & --- & --- & -- & --- \\
\hline III & --- & --- & --- & --- & -- \\
\hline IV & --- & --- & --- & --- & - \\
\hline V & --- & --- & --- & & \\
\hline
\end{tabular}

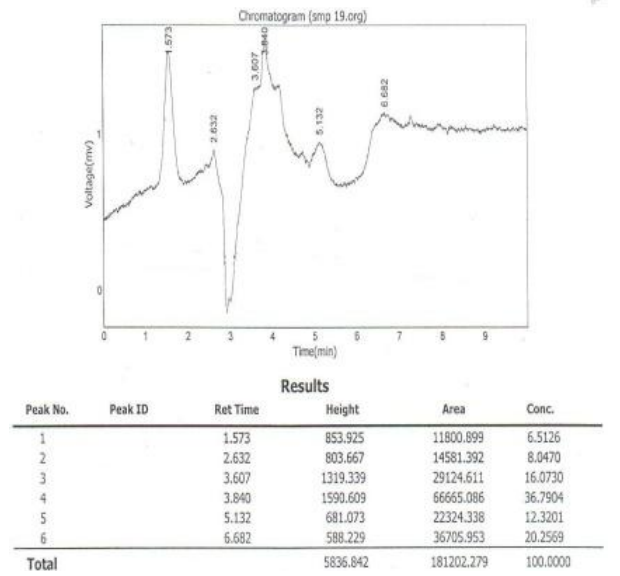

Fig27: Sample taken from Jinnah Abad, Abbottabad in which No nitro-PAH was detected
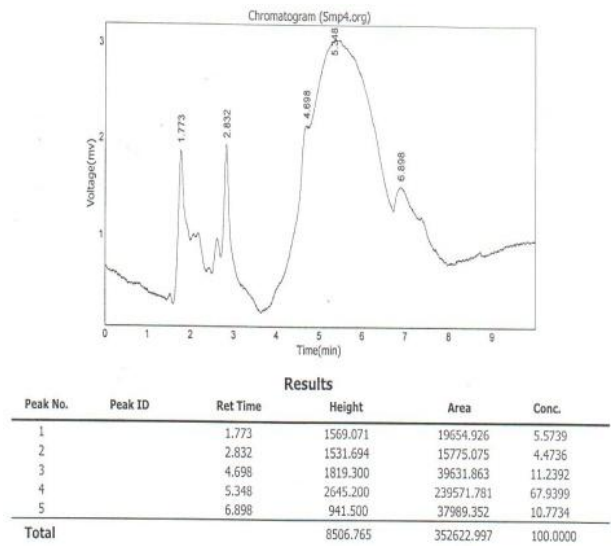

Fig28: Sample taken from Jinnah Abad, Abbottabad in which No nitro-PAH was detected

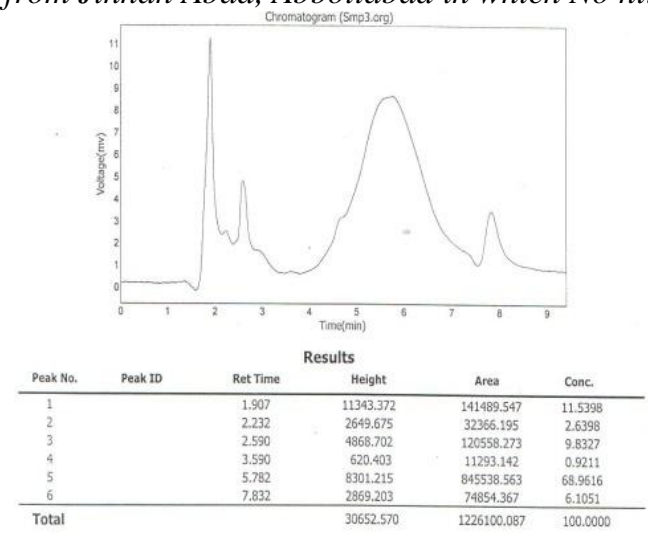

Fig29: Sample taken from Jinnah Abad, Abbottabad in which No nitro-PAH was detected 


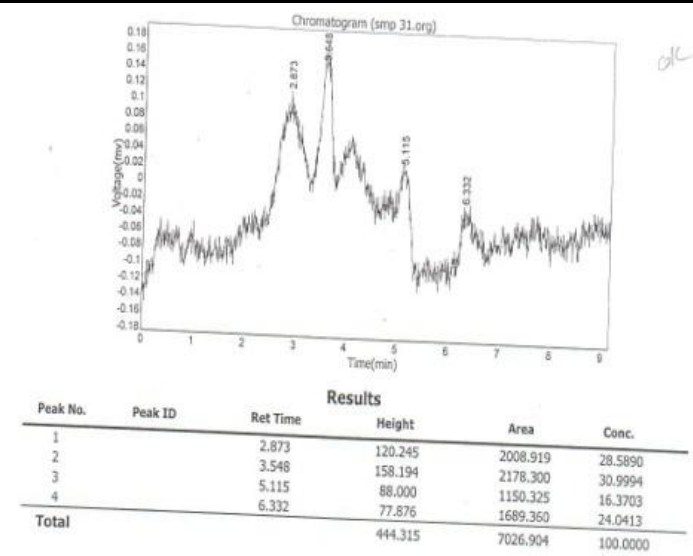

Fig30: Sample taken from Jinnah Abad, Abbottabad in which No nitro-PAH was detecte

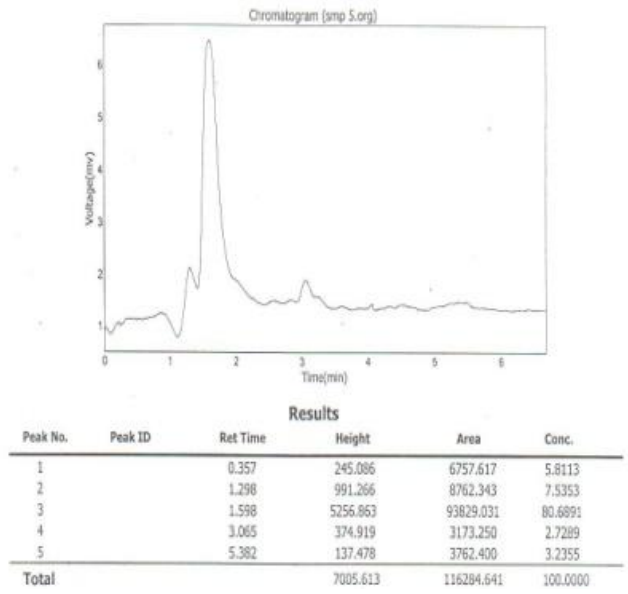

Fig31: Sample taken from Jinnah Abad, Abbottabad in which No nitro-PAH was detected

\section{Water Sample Taken From Qalandarabad, Abbottabad}

The chromatograms obtained from samples collected from Qalanderabad, Abbottabad are described in table 8 and the chromatograms are presented in figure 40 to 45 . No nitro-PAHs were detected because the samples were collected from an area whose water source is of natural springs.

Table 8: Water sample taken from Qalanderabad, Abbottabad

\begin{tabular}{|c|c|c|c|c|c|}
\hline \multirow{2}{*}{ Smp. \# } & \multicolumn{5}{|c|}{ Nitro PAHs (ng/ Liter) } \\
\cline { 2 - 6 } & $1-N N$ & $2-N F$ & $9-N A$ & $3-N F A$ & $1-N P$ \\
\hline I & --- & --- & --- & --- \\
\hline II & --- & --- & --- & --- & -- \\
\hline III & --- & --- & --- & -- \\
\hline IV & --- & --- & --- & -- \\
\hline V & --- & --- & --- & --- & -- \\
\hline VI & --- & --- & --- & -- \\
\hline
\end{tabular}

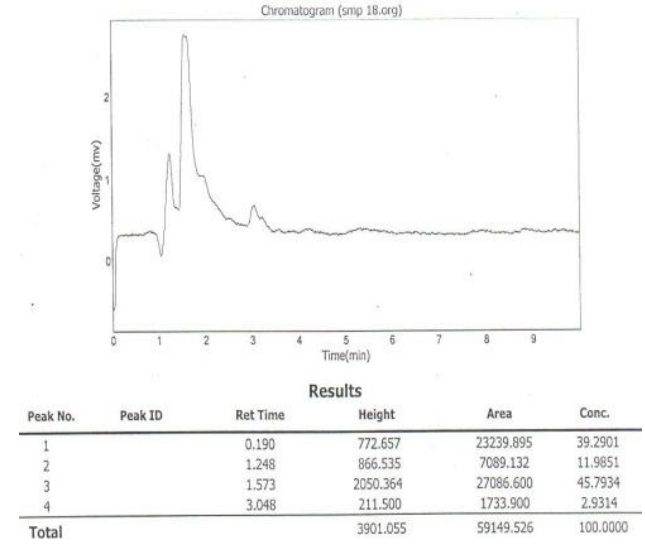

Fig40: Sample taken from Qalanderabad, Abbottabad in which No nitro-PAH was detected 
Comparative Study of Nitrated Aromatic Hydrocarbons in Drinking Water samples taken from Hattar industrial area, TIP housing society, Hazara University Dhodial Mansehra and Kahuta industrial triangle Islamabad, Pakistan

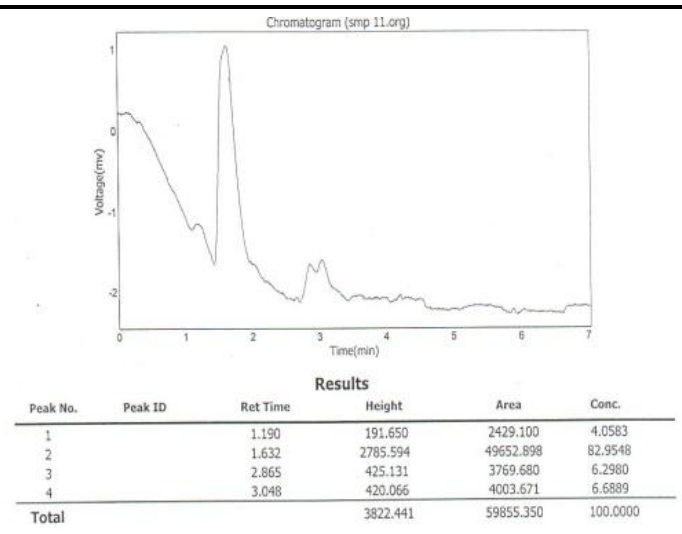

Fig32: Sample taken from Qalandarabad, Abbottabad in which No nitro-PAH was detected
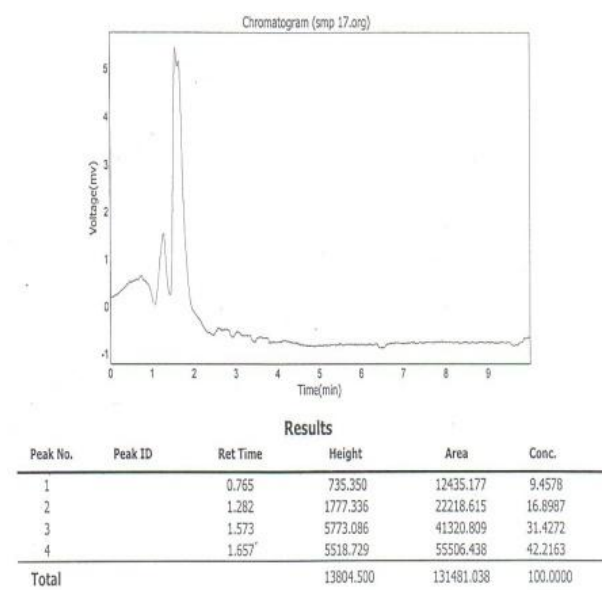

Fig33: Sample taken from Qalanderabad, Abbottabad in which No nitro-PAH was detected

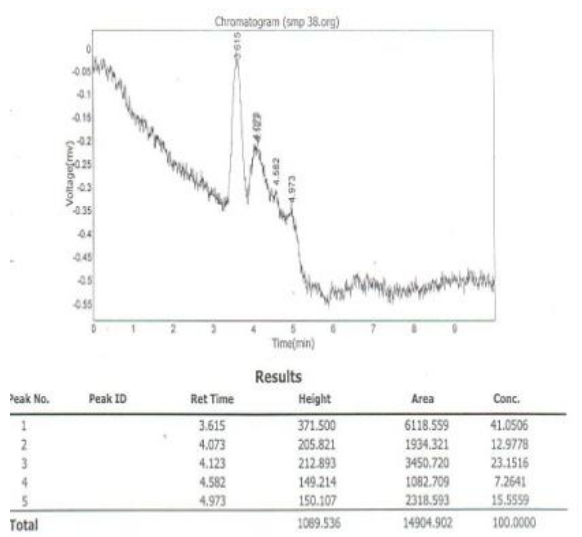

Fig34: Sample taken from Qalanderabad, Abbottabad in which No nitro-PAH was detected

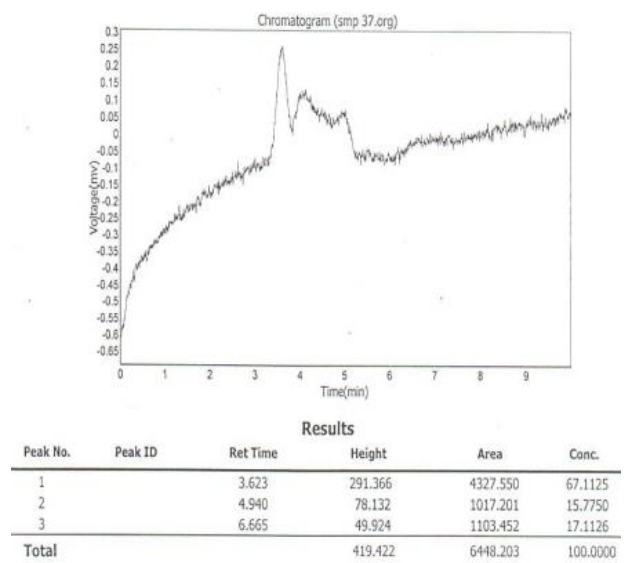

Fig35: Sample taken from Qalanderabad, Abbottabad in which No nitro-PAH was detected 


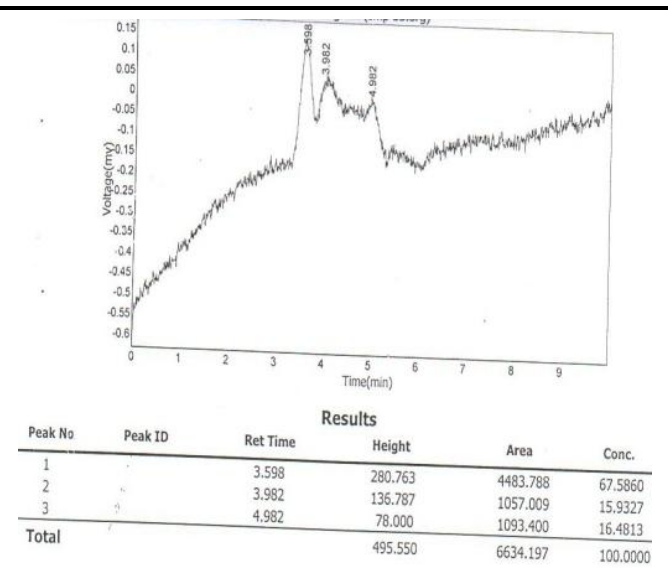

Fig36: Sample taken from Qalanderabad, Abbottabad in which No nitro-PAH was detected

\section{Water Sample Taken From National Industrial Zone Rawat, Islamabad}

Table 9 shows the list of samples which were collected from National Industrial Zone, RawatIslamabad. No nitro-PAH were detected in all these samples as shown in the figure 46 to 52 below. National industrial zone Rawat is a bit planned industrial zone having less industries and a good sewage system. That's why no nitro-PAHs were detected in the samples collected from NIZ, Rawat, Islamabad.Results are summarized in table 9 and the chromatograms are shown in figures 46 to 52

Table 9: Water sample taken from National Industrial Zone Rawat, Islamabad

\begin{tabular}{|c|c|c|c|c|c|}
\hline \multirow{2}{*}{ Smp. \# } & \multicolumn{5}{|c|}{ Nitro PAHs (ng/ Liter) } \\
\cline { 2 - 6 } & $I-N N$ & $2-N F$ & $9-N A$ & $3-N F A$ & $1-N P$ \\
\hline I & --- & --- & --- & --- & --- \\
\hline II & --- & --- & --- & --- & --- \\
\hline III & --- & --- & --- & --- & --- \\
\hline IV & --- & --- & --- & -- \\
\hline V & --- & --- & --- & --- \\
\hline VI & --- & --- & --- & --- \\
\hline VII & --- & --- & --- & - & \\
\hline
\end{tabular}
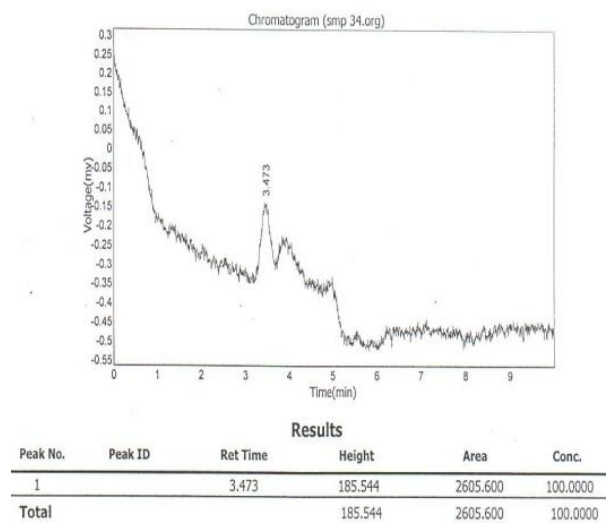

Fig37: Sample taken from National Industrial Zone Rawat, in this sample no nitro-PAH was detected

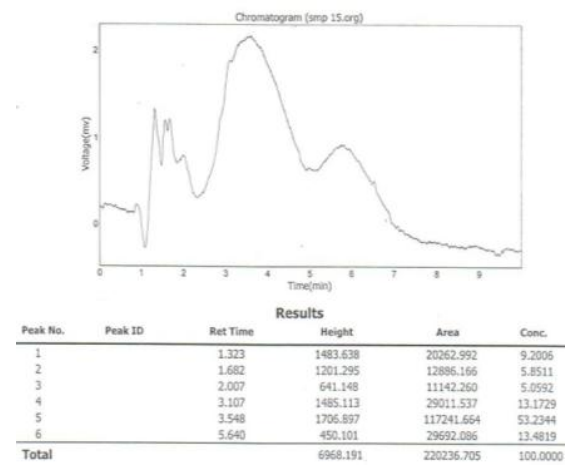

Fig38: Sample taken from National Industrial Zone Rawat, no nitro-PAH was detected 
Comparative Study of Nitrated Aromatic Hydrocarbons in Drinking Water samples taken from Hattar industrial area, TIP housing society, Hazara University Dhodial Mansehra and Kahuta industrial triangle Islamabad, Pakistan

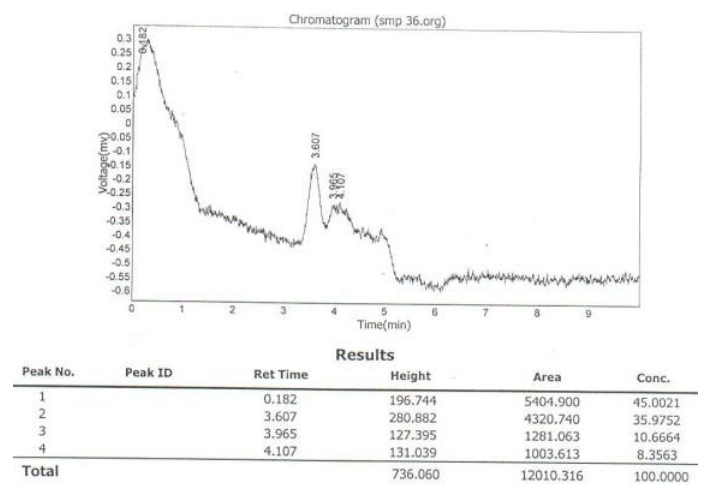

Fig39: Sample taken from National Industrial Zone Rawat, no nitro-PAH was detected

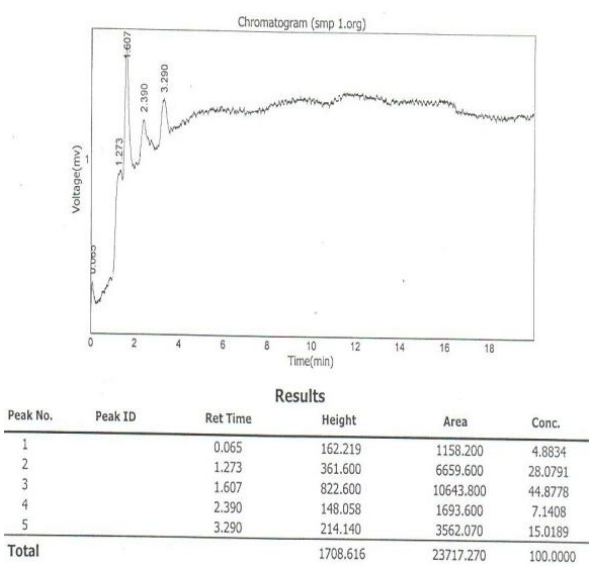

Fig40: Sample taken from National Industrial Zone Rawat, no nitro-PAH was detected

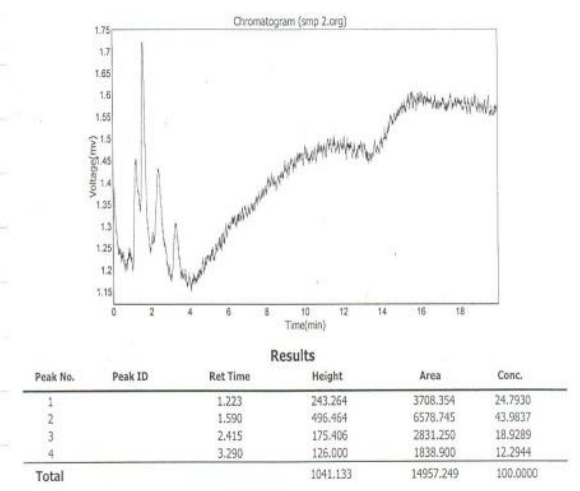

Fig41: Sample taken from National Industrial Zone Rawat, no nitro-PAH was detected

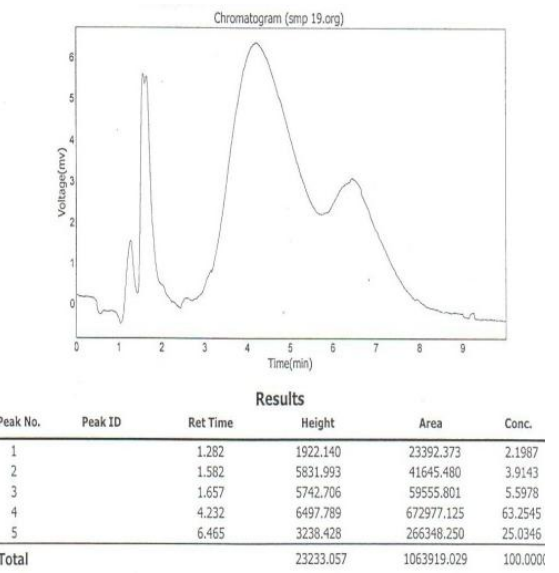

Fig42: Sample taken from National Industrial Zone Rawat, no nitro-PAH was detected 


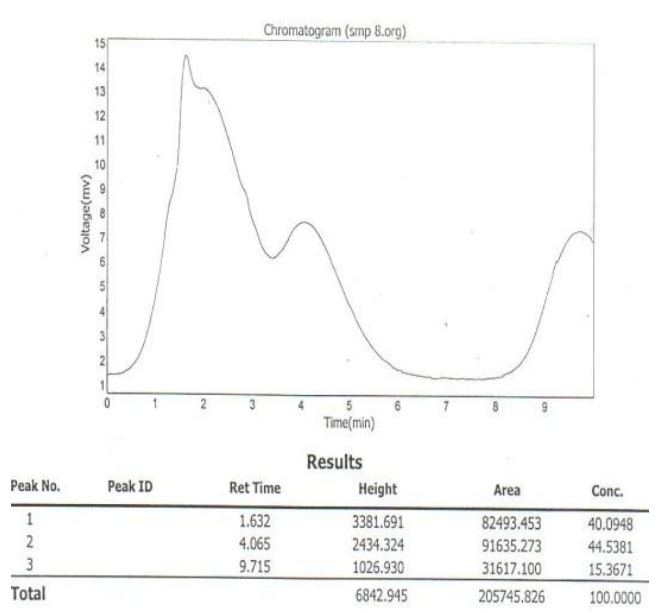

Fig43: Sample taken from National Industrial Zone Rawat, no nitro-PAH was detected

\section{Water Samples Taken From Dhodial, Mansehra}

Table 10 presents the samples collected from Dhodial, Mansehra. In these samples no nitro-PAH is detected probably because of absence of any industries.Results are described in table 10 while chromatograms are shown in figure 53 to 57.

\begin{tabular}{|c|c|c|c|c|c|}
\hline \multirow{2}{*}{ Smp. \# } & \multicolumn{5}{|c|}{ Nitro PAHs (ng/ Liter) } \\
\cline { 2 - 6 } & $1-N N$ & $2-N F$ & $9-N A$ & $3-N F A$ & $1-N P$ \\
\hline I & --- & --- & --- & -- & --- \\
\hline II & --- & --- & --- & -- \\
\hline III & --- & --- & -- & --- \\
\hline IV & --- & --- & --- \\
\hline V & --- & ----- \\
\hline VI & --- & --- & --- & --- & --- \\
\hline
\end{tabular}

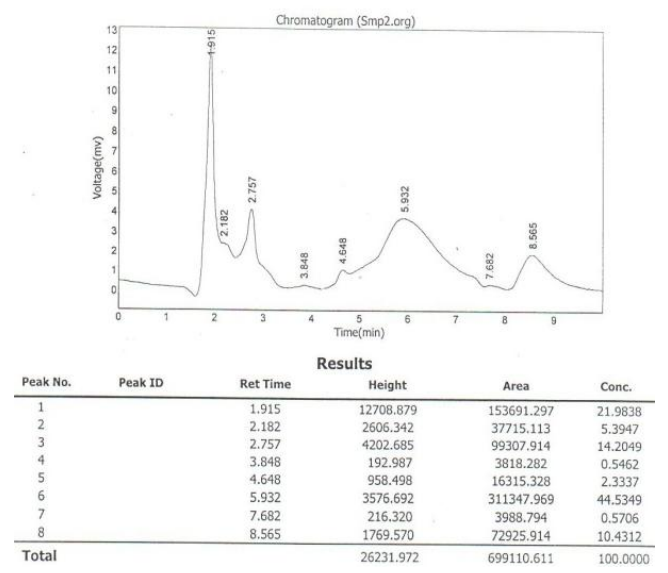

Fig44: Sample taken from Dhodial, Mansehra no nitro-PAH was detected

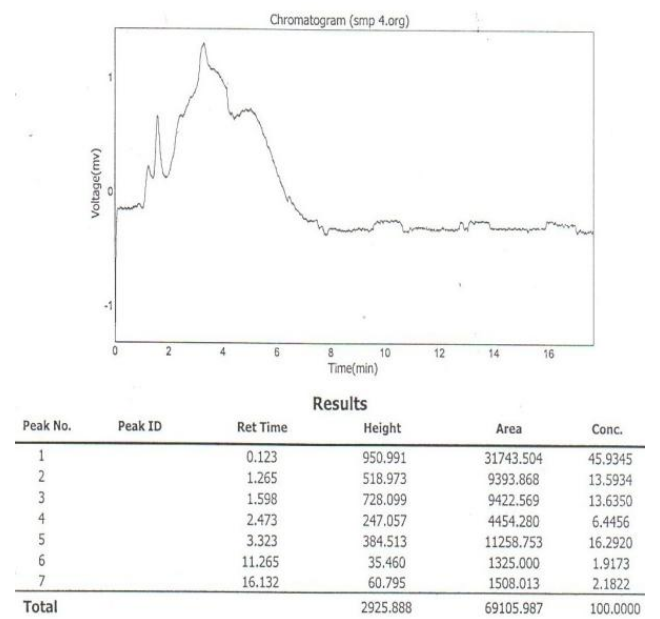

Fig45: Sample taken from Dhodial, Mansehra no nitro-PAH was detected 


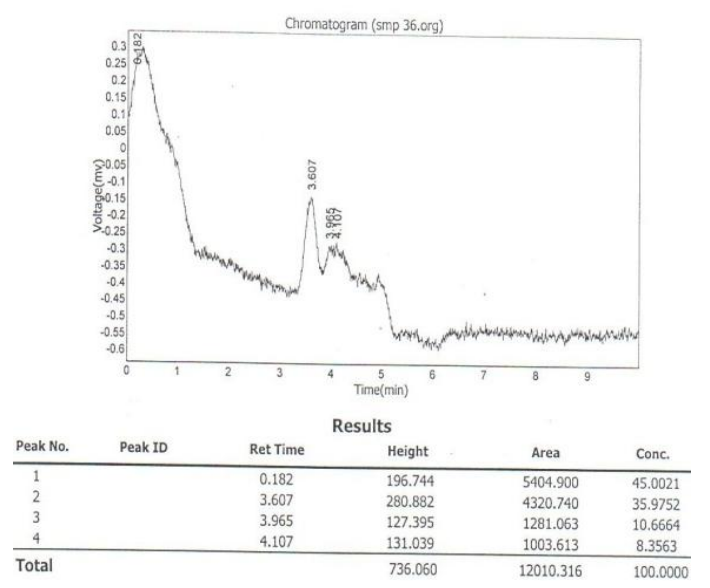

Fig55: Sample taken from Dhodial, Mansehra no nitro-PAH was detected
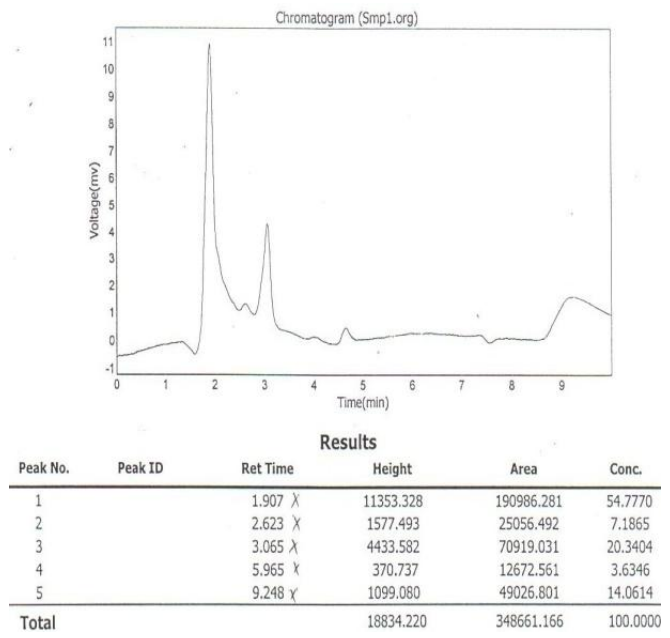

Fig46: Sample taken from Dhodial, Mansehra no nitro-PAH was detected

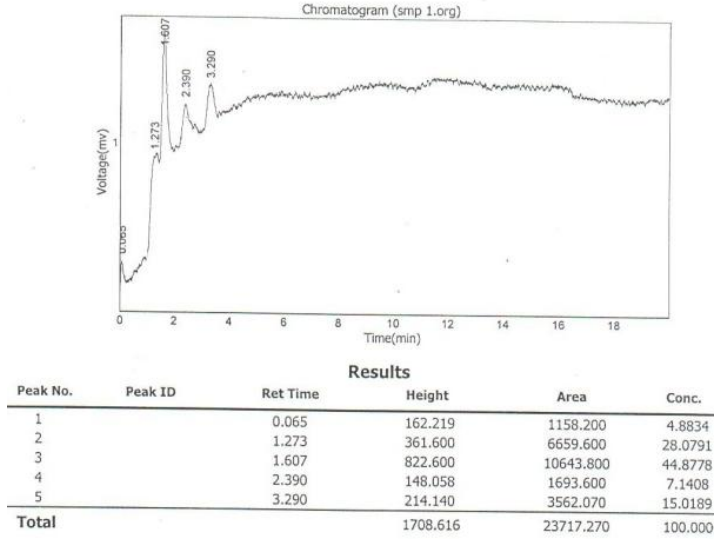

Fig47: Sample taken from Dhodial, Mansehra no nitro-PAH was detected

\section{CONClusion}

50 water samples were taken from Hattar industrial area, TIP housing society, Hazara University DhodialMansehra and Kahuta industrial triangle Islamabad and analyzed with the help of High Pressure Liquid Chromatography for the determination of 5 Nitro PAHs including: Nitronaphthalene, Nitrofluorine, 9-Nitroanthracene, 3-Nitrofluoroanthene, Nitropyrene. Maximum amount 1ng/L of 1$\mathrm{NN}$ was detected in the water samples of Industrial Estate, Hattar. It is concluded that commercial water supplies are safe for health. The underground water near industrial areas particularly Hattar industrial area is not good for human use. While Rawat Industrial Zone is well planned for water supply and drainage so there no nitro PAHs were detected. 


\section{Funding source:}

The analyses were performed by using an HPLC chromatograph in Hazara University Mansehra, Pakistan. Department has provided instruments and chemicals. Sample collection was author's research.

\section{Conflict of interest:}

The authors declare that there is no conflict of interest.

\section{REFERENCES}

[1] BAXTER, C. V., FAUSCH, K. D., MURAKAMI, M. \& CHAPMAN, P. L. 2004. Fish invasion restructures stream and forest food webs by interrupting reciprocal prey subsidies. Ecology, 85, 2656-2663

[2] HUDGiNS, D. M., BAUSCHLICHER JR, C. W. \& ALLAMANDOLA, L. 2005. Variations in the peak position of the $6.2 \mu \mathrm{m}$ interstellar emission feature: A tracer of $\mathrm{N}$ in the interstellar polycyclic aromatic hydrocarbon population. The Astrophysical Journal, 632, 316.

[3] HOOVER, R. 2014. Need to Track Organic Nano-Particles Across the Universe? NASA's Got an App for That" ". NASA. Retrieved 2014

[4] MEINERT, C., DE MARCELLUS, P., LE SERGEANT D'HENDECOURT, L., NAHON, L., JONES, N. C., HOFFMANN, S. V., BREDEHÖFT, J. H. \& MEIERHENRICH, U. J. 2011. Photochirogenesis: photochemical models on the absolute asymmetric formation of amino acids in interstellar space. Physics of life reviews, 8, 307-330.

[5] SRIVASTAVA, S., SINGH, M., GEORGE, J., BHUI, K., MURARI SAXENA, A. \& SHUKLA, Y. 2010. Geno toxic and carcinogenic risks associated with the dietary consumption of repeatedly heated coconut oil. British journal of nutrition, 104, 1343-1352.

[6] YAMAZAKI, H., HATANAKA, N., KIZU, R., HAYAKAWA, K., SHIMADA, N., GUENGERICH, F. P., NAKAJIMA, M. \& YOKOI, T. 2000. Bio activation of diesel exhaust particle extracts and their major nitrated polycyclic aromatic hydrocarbon components, 1nitropyrene and dinitropyrenes, by human cytochromes P450 1A1, 1A2, and 1B1. Mutation Research/Genetic Toxicology and Environmental Mutagenesis, 472, 129-138.

[7] DUTTA, K., GHOSH, D., NAZMI, A., KUMAWAT, K. L. \& BASU, A. 2010. A common carcinogen benzo [a] pyrene causes neuronal death in mouse via microglial activation. PLoS One, 5, e9984.

[8] Yutaka K, Junko S, Takeshi K et al., 2005. Atmospheric polycyclic aromatic hydrocarbons: size distribution, estimation of their risk and their depositions to the human respiratory tract[J]. Sci Total Environ, 340: 71-80

[9] MöllerL, LaxI, ErikssonL. Nitrated polycyclic aromatic hydrocarbons: a risk assessment for the urban citizen. Environ Health Perspect. 1993 Oct; 101(Suppl 3): 309-315.

[10] Bezabeh D, Holly H, Schantz M. Determination of nitrated polycyclic aromatic hydrocarbons in diesel particulate-related standard reference materials by using gas chromatography/mass spectrometry with negative ion chemical ionization[J]. Anal BioanalChem, 2003. 375: 381- 388.

[11] JACQUET, M., LAMBERT, V., TODARO, A. \& KREMERS, P. 1997. Mitogen-activated lymphocytes: a good model for characterizing lung CYP1A1 inducibility. European journal of epidemiology, 13, 177-183.

[12] DIMASHKI, M., HARRAD, S. \& HARRISON, R. M. 2000. Measurements of nitro-PAH in the atmospheres of two cities. Atmospheric Environment, 34, 2459-2469.

[13] Bamford HA, Bezabeh DZ, Schantz S, Wise SA, Baker JE. Determination and comparison of nitrated-polycyclic aromatic hydrocarbons measured in air and diesel particulate reference materials.Chemosphere. 2003; 50 (5):575-87.

[14] Chetwittayachan T, Shimazaki D, Yamamoto K, 2002. A comparison of temporal variation of particle-bound polycyclic aromatic hydrocarbons (pPAHs) concentration in different urban environments: Tokyo, Japan, and Bangkok, Thailand [J]. Atmos Environ, 36: 2027-2037.

[15] Hayakawa K, 2000. Chromatographic methods for carcinogenic/mutagenic nitropolycyclic aromatic hydrocarbons [J]. Biomed Chromatogr, 14: 397-405. 
Comparative Study of Nitrated Aromatic Hydrocarbons in Drinking Water samples taken from Hattar industrial area, TIP housing society, Hazara University Dhodial Mansehra and Kahuta industrial triangle Islamabad, Pakistan

[16] Hayakawa K, Tang N, Akutsu K et al., 2002. Comparison of polycyclic aromatic hydrocarbons and nitropolycyclic aromatic hydrocarbons in airborne particulates collected in downtown and suburban Kanazawa, Japan[J]. Atmos Environ, 36: 5535-5541.

[17] Romero R, Sienra R, Richter P, 2002. Efficient screening method for determination of polycyclic aromatic hydrocarbons (PAHs) in airborne particles. Application in real samples of SantiagoChile metropolitan urban area[J]. Atmos Environ, 36: 2375-2381. 